\title{
PENDUGAAN MODEL PARTISIPASI EKONOMI MASYARAKAT PROVINSI JAMBI DENGAN METODE ANALISIS REGRESI LOGISTIK BINER
}

\author{
Gusmi Kholijah \\ Prodi Matematika Fakultas Sains dan Teknologi Universitas Jambi \\ gusmikholijah@unja.ac.id
}

\begin{abstract}
Abtrak:
Kesejahteraan ekonomi masih belum merata di Indonesia. Hal ini masih menjadi masalah dalam mengatasi kemiskinan. Banyak usaha yang sudah dilakukan dalam pengentasan kemiskinan, salah satunya meningkatkan partisipasi ekonomi. Partisipasi ekonomi dapat dikategorikan atas bekerja dan tidak bekerja. Partisipasi ekonomi merupakan variabel respon yang dipengaruhi oleh beberapa variabel prediktor. Hubungan antara variabel prediktor dengan variabel respon yang berbentuk kategori biner dapat dianalisis dengan regresi logistik biner. Model yang dihasilkan dari penelitian ini menyampaikan bahwa masyarakat yang tinggal di perdesaan lebih memiliki partisipasi ekonomi dibanding dengan di perkotaan. Lalu status perkawinan dengan kategori kawin, cerai hidup lebih memiliki berpartisipasi ekonomi dibanding dengan cerai mati, dan yang cerai mati lebih berperan lagi dibanding dengan yang belum kawin. Selanjutnya lakilaki lebih berpartisipasi ekonomi dibanding dengan perempuan. Lalu jika dilihat dari usia, menunjukkan usia produktif kerja lebih memiliki partisipasi ekonomi, kemudian semakin tinggi tingkat pendidikan maka memberikan kontribusi terhadap partisipasi ekonomi semakin tinggi.
\end{abstract}

Kata Kunci: Partisipasi Ekonomi, Regresi Logistik Biner

\begin{abstract}
:
Economic well-being is still uneven in Indonesia. This is still a problem in overcoming poverty. Many efforts have been made in poverty alleviation, one of which is increasing economic participation. Economic participation can be categorized as working and not working. Economic participation is a response variable that is influenced by several predictor variables. The relationship between predictor variables and response variables in the form of binary categories can be analyzed by binary logistic regression. The model generated from this study conveys that people who live in rural areas have more economic participation than those in cities. Then marital status in the category of marriage, divorced life has more economic participation than divorce, and divorced people die more than those who have not yet married. Furthermore, men participate more economically than women. Then when viewed from the age, shows the productive age of work has more economic participation, then the higher the level of education then contributes to the higher economic participation.
\end{abstract}

Keywords: Biner Logistic Regression, Economic participation, 


\section{PENDAHULUAN}

Kesejahteraan ekonomi saat ini masih menjadi masalah ekonomi di kalangan masyarakat. tingginya ketidakmerataan ekonomi membuat tingkat kemiskinan diberbagai daerah di Indonesia masih relatif tinggi. Usaha menekan tingkat kemiskinan ini sudah banyak dilakukan, salah satu diantaranya yaitu dengan meningkatkan partisipasi ekonomi masyarakat. Partisipasi ekonomi merupakan kegiatan keikutsertaan masyarakat dalam kegiatan ekonomi. Partisipasi ekonomi dapat dilihat dari tingginya tingkat angkatan kerja dari masyarakat yang dilihat dari lamanya waktu yang digunakan untuk bekerja yang menghasilkan pendapatan. Analisis angkatan kerja dalam kaitannya dengan kondisi perekonomian merupakan hal yang menarik untuk dilakukan karena tingkat dan pola partisipasi angkatan kerja cenderung bergantung pada ketersediaan kesempatan kerja dan perbedaan pada tuntutan memperoleh pendapatan antar kelompok penduduk. Misalnya, partisipasi warga yang tinggal diperkotaan dan perdesaan dalam angkatan kerja cenderung berbeda antar kelompok umur, status perkawinan dan perbedaan tingkat pendidikan serta jenis kelamin. Jadi, adanya perbedaan variabel ini akan memberikan analisis tentang partisipasi ekonomi dalam suatu daerah.

Penelitian sebelumnya yang membahas tentang angkatan kerja ini dilakukan oleh Sulistriyanti (2015) dengan metode analisis regresi berganda menyampaikan bahwa variabel tingkat pendidikan, pendapatan suami dan jumlah anggota keluarga memiliki pengaruh positif terhadap partisipasi kerja perempuan di Kota Pekanbaru. Kemudian penelitian yang dilakukan oleh Resmiati (2018) dengan model probit memperoleh bahwa usia, pendidikan, memiliki pengaruh positif terhadap partisipasi kerja perempuan menikah di Indonesia dan lokasi tempat tinggal berpengaruh negatif dengan probabilitas yang diperoleh $2,7 \%$ perempuan yang tinggal di perkotaan bekerja lebih rendah dibanding yang di perdesaan.

Partisipasi ekonomi masyarakat dapat dibedakan kepada kategori bekerja dan tidak bekerja. Variabel kategori partisipasi ekonomi ini dinamakan dengan variabel respon yang terdiri dari dua kategori yang dipengaruhi oleh beberapa variabel prediktor, sehingga untuk menganalisis partisipasi ekonomi ini dapat dilakukan dengan analisis regresi logistik biner. Oleh karena itu, penelitian ini bertujuan untuk menganalisis partisipasi ekonomi masayarakat dengan menggunakan analsiis regresi logistik biner.

Regresi logistik biner digunakan untuk pemodelan variabel respon $(Y)$ bersifat biner. Biner menunjukkan pada pemakaian dua buah bilangan 0 dan 1 untuk menggantikan dua kategori pada variabel respon. Menurut Hosmer \& Lemeshow (2000), regresi logistik biner merupakan metode analisis statistika yang mendeskripsikan hubungan antara variabel respon yang memiliki dua kategori atau lebih dengan satu atau lebih variabel prediktor yang berskala kategori. Kejadian variabel respon $Y$ mengikuti sebaran Bernoulli dengan fungsi sebaran peluang : 


$$
P(Y=y)=\pi^{y}(1-\pi)^{1-y}
$$

dengan $y=\{0,1\}$ dan $\pi$ adalah peluang kejadian bernilai $Y=1$.

Hosmer \& Lemeshow (2000) menjelaskan bahwa bentuk model regresi logistik dengan $P(Y=$ $1 \mid x)=\pi(x)$ adalah:

$$
\pi(x)=\frac{\exp (g(x))}{1+\exp (g(x))}
$$

dengan $g(x)=\beta_{0}+\beta_{1} x_{1}+\cdots+\beta_{p} x_{p}$

dengan:

$\beta_{0}=$ konstanta

$\beta_{1}=$ koefisien regresi logistik $(i=1,2, \ldots, p)$

$p=$ banyaknya variabel prediktor

Fungsi di atas berbentuk non linier, sehingga untuk membentuk fungsi linier dilakukan transformasi logit sebagai berikut (Agresti 1990) :

$$
\operatorname{logit}[\pi(x)]=\ln \left[\frac{\pi(x)}{1-\pi(x)}\right]=g(x)=\beta_{0}+\beta_{1} x_{1}+\cdots+\beta_{p} x_{p}
$$

$g(x)$ merupakan penduga logit sebagai fungsi linier dari variabel prediktor, dengan kemungkinan nilai peluang terbesar adalah 1 .

Pendugaan koefisien model regresi logistik dapat dilakukan dengan metode kemungkinan maksimum (maximum likelihood estimation/MLE) yaitu diperoleh dengan mendiferensialkan fungsi kepekatan peluang gabungan (Hosmer \& Lemeshow 2000). Selanjutnya pengujian parameter model dilakukan untuk mengetahui peranan variabel prediktor yang terdapat di dalam model. Statistik uji likelihood ratio untuk menguji peranan peubah penjelas secara serentak atau keseluruhan. Rumus umum statistik uji $G$ adalah:

$G=-2 \ln \left[\frac{L_{0}}{L_{1}}\right]$

dengan $L_{0}$ merupakan nilai kemungkinan tanpa variabel prediktor dan $L_{1}$ adalah nilai kemungkinan dengan variabel prediktor. Hipotesis yang digunakan, yaitu :

$H_{0}: \beta_{1}=\ldots .=\beta_{p}=0$

$H_{1}$ : minimum terdapat satu $\beta_{i} \neq 0,(i=1,2 \ldots, p)$

Statistik uji $G$ mengikuti sebaran $\chi^{2}$ dengan derajat bebas $p$. Kaidah keputusan yang diambil adalah jika nilai $G>\chi_{\alpha ; p}^{2}$ atau nilai $p$ value $<\alpha$ maka hipotesis nol ditolak.

Selain itu dilakukan pengujian secara parsial untuk masing-masing koefisien variabel menggunakan statistik uji Wald. Hipotesis yang digunakan,yaitu:

$H_{0}: \beta_{i}=0$

$H_{1}: \beta_{i} \neq 0,(i=1,2, \ldots, p)$ 
Statistik uji Wald yaitu: $W=\frac{\widehat{\beta_{l}}}{S E\left(\widehat{\beta_{l}}\right.}$

Nilai $\widehat{\beta}_{l}$ merupakan estimasi koefisien dari masing-masing variabel prediktor, sedangkan $S E\left(\widehat{\beta}_{l}\right)$ adalah simpangan baku dari estimasi masing-masing parameternya. Nilai uji Wald mengikuti sebaran Khi Kuadrat, dengan daerah penolakan $H_{0}$ adalah jika $W>\chi_{a ; p}^{2}$ dengan derajat bebas $p$.

Menurut Hosmer \& Lemeshow (2000) salah satu ukuran kebaikan model adalah jika memiliki peluang salah klasifikasi yang minimal. Ketepatan prediksi dari model dapat diketahui dengan menggunakan tabel ketepatan klasifikasi (correct classification table).

\section{METODE}

Data yang digunakan dalam penelitian ini adalah data sekunder yang diambil dari data SUSENAS BPS tahun 2018 Provinsi Jambi. Objek penelitiaannya tentang partisipasi ekonomi masyarakat Provinsi Jambi dengan variabel penelitian terdiri dari variabel respon dan variabel prediktor. Variabel responnya yaitu partisipasi ekonomi yang terdiri dari kategori bekerja (1) dan tidak bekerja (0). Sedangkan variabel prediktornya adalah klasifikasi daerah yang terdiri atas kategori perkotaan dan perdesaan, selanjutnya variabel status perkawinan dengan kategori belum kawin, kawin, cerai hidup dan cerai mati. Lalu ada variabel usia, variabel jenis kelamin yang terdiri dari kategori laki-laki dan perempuan. Kemudian variabel prediktor yang terakhir yaitu tingkat pendidikan yang terdiri dari kategori SD, SMP, SMA dan PT. Tahapan dalam penelitian ini antara lain: menentukan model regresi logistik antara variabel respon dengan variabel prediktor kemudian menginterpretasikan model regresi logistik biner pada partisipasi ekonomi masyarakat Provinsi Jambi.

\section{HASIL DAN PEMBAHASAN}

Penelitian mengenai partisipasi ekonomi masyarakat menggunakan regresi logistik biner dengan variabel prediktor yaitu klasifikasi daerah, status perkawinan, usia, jenis kelamin dan tingkat pendidikan dapat dilihat apakah memiliki hubungan berpengaruh antar variabel secara bersama-sama dengan hipotesis dibawah ini:

Tabel 1: Uji Variabel Secara Bersama-sama

\begin{tabular}{cccc}
\hline Step & $\begin{array}{c}-2 \text { Log } \\
\text { likelihood }\end{array}$ & $\begin{array}{c}\text { Cox \& Snell R } \\
\text { Square }\end{array}$ & $\begin{array}{c}\text { Nagelkerke R } \\
\text { Square }\end{array}$ \\
\hline 1 & $20419.130^{\mathrm{a}}$ & 0.390 & 0.522 \\
\hline
\end{tabular}

Hipotesis:

$H_{0}: \beta=0$ 
$H_{1}: \beta \neq 0$

$\alpha=0,05$

Statistik Uji: $G^{2}=-2 \ln \left[\frac{L_{0}}{L_{1}}\right]=20419.130$

dengan daerah penolakan $H_{0}: G^{2}>\chi_{(0,05 ; 5)}^{2}=11.07$

Keputusan yang diambil adalah tolak $H_{0}$. Artinya minimal ada satu variabel prediktor yang berpengaruh signifikan terhadap variabel partisipasi ekonomi.

Kemudian untuk mengetahui pengaruh masing-masing variabel prediktor dapat dilakukan dengan melakukan pengujian signifikansi parameter secara parsial dengan uji Wald sebagai berikut: Hipotesis:

$H_{0}: \beta_{i}=0$

$H_{1}: \beta_{i} \neq 0,(i=1,2, \ldots, p)$

$\alpha=5 \%$

$W=\frac{\widehat{\beta}_{l}}{S E\left(\widehat{\beta}_{l}\right.}$

Daerah penolakannya $H_{0}:\left|\mathrm{W}_{\text {hit }}\right|>Z_{\alpha / 2}=1,96$.

Tabel 2: Uji masing-masing variabel

\begin{tabular}{lcccccr}
\hline & B & S.E. & Wald & df & Sig. & Exp(B) \\
\hline Klasifikasi_daerah(1) & -.185 & .040 & 21.171 & 1 & .000 & .831 \\
\hline Status_Perkawinan & & & 1930.192 & 3 & .000 & \\
\hline Status_Perkawinan(1) & -1.248 & .109 & 130.202 & 1 & .000 & .287 \\
\hline Status_Perkawinan(2) & 1.000 & .080 & 155.906 & 1 & .000 & 2.719 \\
\hline Status_Perkawinan(3) & 1.484 & .151 & 96.528 & 1 & .000 & 4.410 \\
\hline Jenis_Kelamin(1) & 1.967 & .042 & 2209.256 & 1 & .000 & 7.149 \\
\hline Usia & .033 & .002 & 448.369 & 1 & .000 & 1.034 \\
\hline Tingkat_pendidikan & & & 859.976 & 3 & .000 & \\
\hline Tingkat_pendidikan(1) & 1.266 & .076 & 278.670 & 1 & .000 & 3.545 \\
\hline Tingkat_pendidikan(2) & -.501 & .047 & 111.506 & 1 & .000 & .606 \\
\hline Tingkat_pendidikan(3) & .422 & .054 & 62.000 & 1 & .000 & 1.525 \\
\hline Constant & -2.171 & .123 & 310.555 & 1 & .000 & .114 \\
\hline
\end{tabular}

Tabel 2 diatas memperlihatkan nilai Wald masing-masing variabel. Tabel diatas menyampaikan bahwa nilai dari Wald $_{\text {hit }}>1,96$, hal ini mengartikan bahwa masing -masing variabel prediktor klasifikasi daerah, status perkawinan, jenis kelamin, usia dan tingkat pendidikan memiliki pengaruh atau signifikan terhadap model secara sendiri-sendiri. 
Selanjutnya yang dilakukan adalah menguji kesesuaian model untuk mengetahui apakah model regresi logistik biner yang didapatkan telah sesuai atau tidak. Adapun bentuk hipotesis yang dipakai yaitu:

$\mathrm{H}_{0}$ : Model tidak sesuai

$\mathrm{H}_{1}$ : Model sesuai

$\alpha=0,05$

pengujian kesesuaian model ini dapat dilakukan dengan menggunakan uji Hosmer and Lemeshow. Keputusan dari pengujian ini yaitu jika Hosmer - Lemoshow $>\chi_{0,05 ; 4}^{2}=9.49$ maka keputusan tolak $H_{0}$.

Tabel 3: Uji Hosmer and Lemeshow

\begin{tabular}{ccc}
\hline Chi-square & Df & Sig. \\
\hline 1111.998 & 8 & .000 \\
\hline
\end{tabular}

Uji Hosmer and Lemeshow diatas menyampaikan bahwa nilai Hosmer - Lemoshow $>\chi_{0,05 ; 4}^{2}=$ 9.49 sehingga keputusan yang diambil adalah tolak $H_{0}$ yang mengartikan bahwa model ini sesuai untuk partisipasi ekonomi masyarakat Provinsi Jambi. Oleh karena itu, model regresi logistik biner untuk penelitian ini adalah:

$$
\hat{\pi}(x)=\frac{\exp \left(-2.17-0.18 x_{1}(1)-1.248 x_{2}(1)+x_{2}(2)+1.48 x_{2}(3)+1.97 x_{3}(1)+0.033 x_{4}+1.27 x_{5}(1)-0.5 x_{5}(2)+0.422 x_{5}(3)\right)}{1+\exp \left(-2.17-0.18 x_{1}(1)-1.248 x_{2}(1)+x_{2}(2)+1.48 x_{2}(3)+1.97 x_{3}(1)+0.033 x_{4}+1.27 x_{5}(1)-0.5 x_{5}(2)+0.422 x_{5}(3)\right)}
$$

Selanjutnya dilakukan interpretasi terhadap model yang diperoleh ini. Model ini dapat dibentuk dalam model logit, sehingga bentuk modelnya yaitu:

$\hat{g}(x)=-2.17-0.18 x_{1}(1)-1.248 x_{2}(1)+x_{2}(2)+1.48 x_{2}(3)+1.97 x_{3}(1)+0.033 x_{4}+1.27 x_{5}(1)-0.5 x_{5}(2)+0.422 x_{5}(3)$

Kemudian dihitung nilai dari odds rasio dari model ini yang dapat dilihat pada tabel berikut ini:

Tabel 4: Odds Rasio Parameter Model

\begin{tabular}{lc}
\hline \multicolumn{1}{c}{ Variabel } & $\operatorname{Exp}(\hat{\beta})$ \\
\hline Klasifikasi daerah $\left(x_{1}(1)\right)$ & 0.83 \\
\hline Status perkawinan $\left(x_{2}(1)\right)$ & 0.29 \\
\hline Status perkawinan $\left(x_{2}(2)\right)$ & 2.72 \\
\hline Status perkawinan $\left(x_{2}(3)\right)$ & 4.41 \\
\hline Jenis kelamin $\left(x_{3}(1)\right)$ & 7.15 \\
\hline Usia $\left(x_{4}\right)$ & 1.03 \\
\hline Tingkat pendidikan $\left(x_{5}(1)\right)$ & 3.55 \\
\hline Tingkat pendidikan $\left(x_{5}(2)\right)$ & 0.61 \\
\hline Tingkat pendidikan $\left(x_{5}(3)\right)$ & 1.53 \\
\hline
\end{tabular}

Tabel nilai odds rasio diatas menyampaikan bahwa untuk variabel klasifikasi desa untuk kategori perkotaan diperoleh odds rasio sebesar 0.83 , hal ini mengartikan bahwa masyarakat yang tinggal di perkotaan memiliki peran 0.83 kali dibanding masyarakat di perdesaan terhadap partisipasi 
terhadap ekonomi atau diartikan masyarakat di perdesaan 1.2 kali lebih berpartisipasi terhadap ekonomi dibanding masyarakat di perkotaan. Kemudian status perkawinan dengan kategori belum kawin memiliki odd rasio sebesar 0.29 dibanding dengan kategori cerai mati, ini mengartikan bahwa masyarakat yang cerai mati 3.45 kali lebih berpartisipasi terhadap ekonomi dibanding dengan yang belum kawin, lalu untuk kategori kawin menyampaikan 2.72 kali lebih berperan terhadap partisipasi ekonomi dibanding dengan kategori cerai mati, sedangkan kategori cerai hidup memiliki odds ratio 4.41 yang menyampaikan bahwa sebesar 4.41 kali yang kategori cerai hidup lebih berperan terhadap partisipasi ekonomi dibanding dengan kategori cerai mati. Selanjutnya untuk variabel jenis kelamin menyampaikan bahwa kategori jenis kelamin laki-laki 7.15 kali lebih berpartisipasi ekonomi dibanding dengan jenis kelamin perempuan. Kemudian untuk variabel usia diperoleh odds ratio sebesar 1.03, hal ini menunjukkan bahwa semakin meningkatnya usia satu satuan dalam rentang produktif kerja menyampaikan partisipasi terhadap ekonomi naik sebesar 1.03. Sedangkan variabel tingkat pendidikan kategori PT memiliki peran 3.55 kali lebih berpartisipasi terhadap ekonomi dibanding dengan pendidikannya SMP, lalu untuk kategori tingkat pendidikan SD 0.61 kali dibanding SMP atau 1.64 kali lebih berperan lulusan SMP terhadap partisipasi ekonomi dibanding dengan lulusan SD, sedangkan tingkat pendidikan SMA menyampaikan bahwa 1.53 kali lebih memiliki peran terhadap partisipasi ekonomi dibanding dengan lulusan SMP.

Kemudian dilakukan ketepatan prediksi pada partispasi ekonomi masyarakat Provinsi Jambi dengan menggunakan tabel klasifikasi dibawah ini:

Tabel 5: Ketepatan Klasifikasi Prediksi

\begin{tabular}{|c|c|c|c|c|}
\hline \multirow{3}{*}{\multicolumn{2}{|c|}{ Obsevasi }} & \multicolumn{3}{|c|}{ Prediksi } \\
\hline & & \multicolumn{2}{|c|}{ Partisipasi_Ekonomi } & \multirow{2}{*}{$\begin{array}{l}\text { ketepatan } \\
\text { persentasi }\end{array}$} \\
\hline & & Tidak bekerja & bekerja & \\
\hline \multirow[t]{2}{*}{ Partisipasi_Ekonomi } & Tidak bekerja & 10294 & 2251 & 82.1 \\
\hline & bekerja & 2998 & 7554 & 71.6 \\
\hline \multicolumn{2}{|l|}{ Persentasi keseluruhan } & & & 77.3 \\
\hline
\end{tabular}

Besarnya ketepatan klasifikasi tidak bekerja diperoleh sebesar $82.1 \%$ dan bekerja sebesar 71.6\%. kemudian secara keseluruhan model regresi logistik biner dapat mengklasifikasikan responden sebesar $77.3 \%$. sedangkan misklasifikasinya yaitu:

$$
\frac{2251+2998}{10294+2251+2998+7554}=22.7 \%
$$

Kesalahan klasifikasi ini sebesar 22,7\% artinya ketepatan klasfikasi sudah diatas $75 \%$ yang menyampaikan bahwa model regresi logistik biner pada partisipasi ekonomi masyarakat Provinsi Jambi ini bisa dianggap baik. 


\section{SIMPULAN}

Bentuk model dari partisipasi ekonomi masyarakat Provinsi Jambi dengan regresi logistik biner yaitu:

$$
\hat{\pi}(x)=\frac{\exp \left(-2.17-0.18 x_{1}(1)-1.248 x_{2}(1)+x_{2}(2)+1.48 x_{2}(3)+1.97 x_{3}(1)+0.033 x_{4}+1.27 x_{5}(1)-0.5 x_{5}(2)+0.422 x_{5}(3)\right)}{1+\exp \left(-2.17-0.18 x_{1}(1)-1.248 x_{2}(1)+x_{2}(2)+1.48 x_{2}(3)+1.97 x_{3}(1)+0.033 x_{4}+1.27 x_{5}(1)-0.5 x_{5}(2)+0.422 x_{5}(3)\right)}
$$

Model ini menyampaikan bahwa masyarakat yang tinggal di perdesaan lebih berpartisipasi terhadap ekonomi dibanding dengan masyarakat yang tinggal di perkotaan. Lalu status perkawinan dengan kategori kawin, cerai hidup lebih memiliki peran terhadap partisipasi ekonomi dibanding yang cerai mati, dan yang cerai mati lebih berperan lagi dibanding dengan yang belum kawin. Sedangkan kategori jenis kelamin lebih berperan lagi terhadap ekonomi dibanding dengan perempuan. Selanjutnya jika dilihat dari usia menunjukkan bahwa semakin seseorang dalam usia produktif bekerja maka lebih memiliki partisipasi terhadap ekonomi, kemudian variabel tingkat pendidikan menyampaikan bahwa semakin tinggi tingkat pendidikan seseorang maka akan memberikan kontribusi terhadap partisipasi kerja semakin tinggi.

\section{REFERENSI}

Agresti A. 1990. Categorical Data Analysis. New Jersey : John Wiley and Sons. 558 p

Garson DG. 2012. Log - Linear, Logit, and Probit Models : Statnotes. North Carolina State University. http://faculty.chass.ncsu. edu/garson/PA765/logit.htm.

Hosmer DW, Lemeshow S. 2000. Applied Logistic Regression, 2nd edition. New York : John Wiley and Sons. $373 \mathrm{p}$

Resmiati, H. N. 2018. Faktor-faktor yang Mempengaruhi Partisipasi Kerja Perempuan Menikah Indonesia. http://eprints.uny.ac.id/id/eprint/63011

Sulistriyanti, F. 2015. Analisis Faktor-faktor yang Mempengaruhi Partisipasi Kerja Perempuan Nikah di Kota Pekanbaru. Jom Fekon Vol. 2 No.2 Oktober 2015. https://jom.unri.ac.id/index.php/JOMFEKON/article/view/11736

Widarjono A. 2010. Analisis Statistika Multivariat Terapan. Yogyakarta : UPP STIM YKPN. 145 hal. 